\title{
STARTING MATERIAL FOR THE BREEDING OF EASILY PRODUCIBLE LENTIL VARIETIES
}

O.M. Bezuhla, L.N. Kobyzeva

Plant Production Institute named after VYa Yuriev of NAAS, Ukraine

Based on results of multi-year studies of a lentil collection, starting material was selected and proposed for the creation of easily producible varieties by the following characteristics: high seed yield (11 macrosperma sources and 25 microsperma sources), suitability for mechanized harvesting (6 macrosperma and 18 microsperma sources); improved biochemical composition and high culinary properties of seeds (3 macrosperma and 10 microsperma sources).

Key words: lentil, collection accessions, yield, protein content, digestibility of seeds, ease of production

Introduction. The daily protein intake by humans is $80-90 \mathrm{~g}$, and the global production of animal protein is 4 -fold as little as the consumption. Legume production is a way to overcome this situation [1]. Of legumes, lentil is among the most valuable ones. This is a multi-purpose crop: food, medicines, fodder (grain, silage, green fodder, chaff, straw, hay) and technical products. As a food crop, lentil is an important producer of biologically valuable easily digestible vegetable protein (21-35\% of protein in seeds), which contains all essential amino acids [2]. Given the economic importance of this crop, high demand for it both in our country and on the world market and the accumulated experience of breeding, the available gene pool opens wide opportunities for the renewal and intensification of lentil cultivation and breeding in Ukraine.

To compete in the market, modern domestic lentil varieties must have at least three main features: high and stable yields in a particular climatic zone, suitability for mechanized harvesting and high quality products. Numerous studies both of Ukrainian [3-5] and of foreign [6] researchers have addressed assessments of the yield capacity of starting material and shown that the yield capacity significantly varied and that climatic conditions influenced the lentil plant development.

As of January 1, 2021, the National Center for Plant Genetic Resources of Ukraine (NCPGRU) has built up a collection comprising 1,101 lentil accessions from 54 countries, including 90 Ukrainian specimens. Of these, $17 \%$ are breeding varieties, $45 \%$ are breeding lines, $37 \%$ are trivially bred varieties and forms, and about $1 \%$ are five wild lentil species. We set the objective to study the collection for traits that determine ease of production and to offer starting material for breeding. Thus, our purpose was to identify sources of valuable economic characteristics for the breeding of easily producible lentil varieties.

Material and methods. The studies were carried out in the Laboratory of Genetic Resources of Grain Legumes and Groats Crops of the NCPGRRU in 1994-2020. Collection specimens were studied in the experimental field of a special crop rotation of the Plant Production Institute named after V.Ya. Yuriev of NAAS (settlement Elitne, Kharkivskyi Raion, Kharkivska

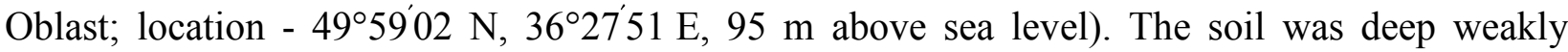
leached chernozem. The forecrop was winter wheat. Farming techniques were conventional for the Forest-Steppe of Ukraine. Sowing was conducted by hand seeders without replication within the optimal for lentil timeframe. The sowing design was $20 \mathrm{~cm} \times 10 \mathrm{~cm}$; the record area was 1 $\mathrm{m}^{2}$. The block of check accessions was placed every 20 collection accessions. The collection accessions were evaluated in compliance with "Guidelines for Studying Legume Genetic Resources" [7].

(C) O.M. Bezugla, L.N. Kobyzeva. 2021.

ISSN 1026-9959. Селекція і насінництво. 2021. Випуск 119. 
Morphological description of the accessions and their categorization by economic and biological features and chemical composition were performed in accordance with the classifier of the genus Lens Mill. [8].

Results and discussion. The lentil collection accessions were grouped by yield level into three classes within the defined ripeness groups. The majority (48\%) of collection lentil accessions gave moderate yields. Mid-ripening accessions gave high yields in the Eastern ForestSteppe of Ukraine (Table 1).

Table 1

Categorization of the collection common lentil (Lens culinaris Medik.) accessions by yield

Ripeness group

Accession number

(growing period)

Total 1 (low yield) 2 (moderate yield) 3 (high yield)

\begin{tabular}{lcccc}
\hline Ultra-early-ripening (<66 days) & 22 & 21 & 1 & - \\
Early-ripening (66-70 days) & 91 & 64 & 32 & 1 \\
Mid-early (71-75 days) & 209 & 68 & 121 & 35 \\
Mid-ripening (76-85 days) & 481 & 52 & 258 & 189 \\
Mid-late (86-90 days) & 167 & 58 & 88 & 36 \\
Late-ripening (91-100 days) & 66 & 26 & 42 & 9 \\
Total & 1,101 & 289 & 542 & 270 \\
\hline
\end{tabular}

We distinguished 270 accessions giving high yields. Of them, breeing varieties Svitanok $\left(260 \mathrm{~g} / \mathrm{m}^{2}\right)$ and Liubava $\left(238 \mathrm{~g} / \mathrm{m}^{2}\right)$, breeding lines LUH 632/04 $\left(299 \mathrm{~g} / \mathrm{m}^{2}\right)$, LUH 633/04 $(258$ $\left.\mathrm{g} / \mathrm{m}^{2}\right)$ and others from Ukraine; breeding varieties Miledi $\left(322 \mathrm{~g} / \mathrm{m}^{2}\right)$, Petrovskaya $6\left(248 \mathrm{~g} / \mathrm{m}^{2}\right)$, Rauza $\left(244 \mathrm{~g} / \mathrm{m}^{2}\right)$ and others from Russia; lines ILL $312\left(329 \mathrm{~g} / \mathrm{m}^{2}\right)$, Flip 96-6L $\left(228 \mathrm{~g} / \mathrm{m}^{2}\right)$ and others from Syria, indicating the high efficiency of breeding in these countries and the feasibility of close cooperation to acquire valuable sources for legume collections of the National Center for Plant Genetic Resources of Ukraine [9].

Over the past five years, the lentil collection has been enriched with 90 accessions. The genetic diversity of lentils is represented by two types of the species Lens culinaris Medik.: macrosperma (16 accessions) and microsperma (74 accessions). Analysis of the yield structure showed that high yields were primarily due to a combination of high number and weight of seeds per plant, therefore, one should pay more attention to these indicators when selecting starting material for the breeding of lentil high-yielding varieties. The number of seeds per plant considerably varies depending on weather conditions. This trait varied 19 to 127 seeds across the macrosperma accessions and from 23 to 204 seeds across the microsperma ones. We selected three microsperma sources of high yield (Table 2).

The yields from the selected accessions exceeded that from the reference accession by 15-24\% due to larger seeds. The 1000-seed weight in Ukrainian local accession UD0601053 and Greek local accessions UD0601054 was $34 \mathrm{~g}$ and $33 \mathrm{~g}$, respectively; in Canadian variety CDC Maxim, it was $36 \mathrm{~g}$, although the seed number per plant was lower than that in the reference accession. Only one Canadian variety, CDC Asterix, had more seeds per plant than the reference accession (201 seeds per plant compared to 145 seeds in the check accession), but this variety is significantly affected by fusarium wilt (40\%), which negatively affects its yield.

No high-yielding, large-seeded accessions, with 1000-seed weight of more than $50 \mathrm{~g}$, have been detected within the last five years. The yields from two local varieties, UD0601077 from Ukraine $\left(161 \mathrm{~g} / \mathrm{m}^{2}\right)$ and UD0601086 from Israel $\left(137 \mathrm{~g} / \mathrm{m}^{2}\right)$, were comparable to that from the reference accession.

The multi-year studies resulted in selection of 11 macrosperma sources of high yield capacity (Krasnohradska 5 originating from Ukraine with a 1000-seed weight of 73 g; 1913 T 15 from Canada - $66 \mathrm{~g}$, UD0600141 from Spain - $91 \mathrm{~g}$ and others) and 25 microsperma sources 
(UD0600707 from Ukraine - 34 g, Miledi from Russia - 38 g, CDC Redcap from Canada - 38 g and others); their yields exceeded those from the check accession Krasnohradska 49 and from the microsperma reference accession Stepnaya 244 by 116-247\%.

Table 2

Characteristics of microsperma lentil accessions with high yields of seeds

\begin{tabular}{|c|c|c|c|c|c|c|c|}
\hline \multirow[b]{2}{*}{$\begin{array}{c}\text { National Cata- } \\
\log \text { No }\end{array}$} & \multirow[b]{2}{*}{ Name } & \multirow[b]{2}{*}{$\begin{array}{c}\text { Country of } \\
\text { origin }\end{array}$} & \multirow[b]{2}{*}{$\begin{array}{c}\text { Seed } \\
\text { number } \\
\text { per } \\
\text { plant }\end{array}$} & \multirow{2}{*}{$\begin{array}{c}\text { Seed } \\
\text { weigh } \\
\text { t per } \\
\text { plant, } \\
\text { g }\end{array}$} & \multirow[b]{2}{*}{$\begin{array}{l}\text { 1000-seed } \\
\text { weight, g }\end{array}$} & \multicolumn{2}{|c|}{ Seed weight $/ \mathrm{m}^{2}$} \\
\hline & & & & & & $\mathrm{g}$ & $\begin{array}{l}\% \text { related } \\
\text { to the } \\
\text { reference } \\
\text { accession }\end{array}$ \\
\hline 2015-2017 & & & & & & & \\
\hline UD0600052 & Stepnaya $244^{1)}$ & RUS & 244 & 6.4 & 26 & 307 & 100 \\
\hline UD0601053 & - & UKR & 204 & 6.9 & 34 & 382 & 124 \\
\hline UD0601054 & - & GRC & 188 & 6.3 & 33 & 354 & 115 \\
\hline $\begin{array}{l}\mathrm{LSD}_{05} \\
2017-2020\end{array}$ & & & & & & 36.4 & \\
\hline UD0600052 & Stepnaya $244^{1)}$ & RUS & 145 & 3.6 & 25 & 190 & 100 \\
\hline UD0600967 & CDC Maxim & CAN & 104 & 3.7 & 36 & 220 & 116 \\
\hline UD0601071 & CDC Asterix & CAN & 201 & 5.3 & 26 & 129 & 68 \\
\hline $\begin{array}{l}\mathrm{LSD}_{05} \\
1)- \text { reference } m\end{array}$ & 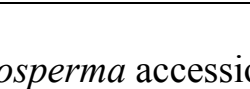 & yield & & & & 28.9 & \\
\hline
\end{tabular}

Suitability for mechanized harvesting is a complex feature, which in lentil consists of resistance of plants to lodging and the lowest pod height above ground level. The bush shape is not a crucial feature here, because, during the bean filling and subsequent developmental stages, generative organs on thin branches of lentil increase their inclination angle from stems, negatively affecting the ease of production of a variety. There are few varieties suitable for mechanized harvesting, which one of the reasons for the lack of industrial lentil crops in Ukraine.

Lodging resistance determines the plant stand height prior to harvest. This feature in combination with a high attachment of the lowest pods (not lower than $15 \mathrm{~cm}$ ) characterizes the ease of production of an accession. We singled out accessions with a high location of the lowest pods above ground level ( $\geq 15 \mathrm{~cm}$ ): 59 macrosperma accessions (from Ukraine: Krasnohradska 250; from Hungary: Iregi cirmos; from Syria: PI 299366 and others) and 73 microsperma accessions (from Ukraine: LUH 125/03; from Slovakia: Zornitsa; from Turkey: Thessalia and others). We also found accessions with high resistance to lodging (7 points): 9 macrosperma accessions (from Ukraine: UD0600969; from Russia: Chakinskaya 319; from Yemen: UD0600143 and others) and 36 microsperma accessions (from Russia: L 135; from Slovakia: Dwarf; from Canada: 2321-6 and others). Six sources of large seeds (from Ukraine: Mistseva 5; from Slovakia: Ilina; from Canada: $1921 \mathrm{~T} 11$ and others) and 18 sources of small seeds (from Russia: Novourenskaya 3565; from the Czech Republic: Pozdnyaya; from Canada: CDC Redwing and others) are suitable for mechanized harvesting. Over the last five years, 5 sources of suitability for mechanized harvesting have been identified (Table 3).

Among them, small-seeded accessions D0601068 from Italy and Orlovskaya Krasnozyornaya from Russia gave higher yields (by $18 \%$ and $10 \%$, respectively) than the check accession. In large-seeded accession UKR001: 01139 from Canada, the height of the lowest pods above ground level exceeded the value in the reference accession for suitability for mechanized harvesting.

Insufficient diversity of starting material in terms of suitability for mechanized harvesting hinders the creation and introduction of lentil varieties into agricultural production. Therefore, it is necessary to pay attention to the development of starting material by bioeasily producible methods, mutagenesis and through other approaches [9]. 
Sources of suitability for mechanized lentil harvesting, 2016-2020

\begin{tabular}{lllccc}
\hline $\begin{array}{c}\text { National Catalog No } \\
\text { or Institution Regis- } \\
\text { tration No }\end{array}$ & \multicolumn{1}{c}{ Accessions } & $\begin{array}{c}\text { Country of } \\
\text { origination }\end{array}$ & $\begin{array}{c}\text { Height of the } \\
\text { lowest pods } \\
\text { above ground } \\
\text { level, cm }\end{array}$ & $\begin{array}{c}\text { Lodging } \\
\text { resistance, } \\
\text { points }\end{array}$ & $\begin{array}{c}\text { Yield } \\
\mathrm{g} / \mathrm{m}^{2}\end{array}$ \\
\hline UD0600036 & Krasnohradska 49 & UKR & 22 & 5 & 214 \\
UD0600509 & Novourenskaya 3565 & RUS & 22 & 7 & 111 \\
UD0601067 & - & ISR & 17 & 7 & 194 \\
UD0601068 & - & ITA & 18 & 7 & 252 \\
UD0601069 & Orlovskaya Krasnozyornaya & RUS & 21 & 7 & 224 \\
UKR001:01099 & - & ISR & 18 & 7 & 85 \\
UKR001:01139 & - & CAN & 23 & 7 & 56 \\
\hline 1) - check accessions; ${ }^{2)}$-reference accession for suitability for mechanized harvesting seeds \\
\hline
\end{tabular}

The protein content in seeds and their cooking qualities are the main features that determine the nutritional value of an accession. MI Smirnova-Ikonnikova [10] categorized legumes into two groups according to variability of the protein content in seeds: strongly responsive to growing conditions (bean, soybean) and weakly responsive (pea, chickpea, lentil). In this regard, it is important and necessary to screen the collected lentil specimens for the protein content in seeds. The maximum protein content in seeds was recorded in mid-early and mid-ripening lentil accessions (Table 4).

Table 4

Protein content in common lentil (Lens culinaris Medik.) seeds in different ripeness groups [9]

\begin{tabular}{lcc}
\hline \multirow{2}{*}{ Ripeness group } & \multicolumn{2}{c}{ Protein content, \% of dry matter } \\
\cline { 2 - 3 } & Min-Max & Mean \\
\hline Early-ripening & $23.75-28.17$ & 25.58 \\
Mid-early & $21.60-29.62$ & 21.60 \\
Mid-ripening & $22.99-30.34$ & 27.07 \\
Late-ripening & $25.17-29.66$ & 28.30 \\
Mean & & 25.64 \\
The total number of analyzed accessions: 479 & \\
\hline
\end{tabular}

Sources with high protein content in seeds were identified: 19 macrosperma accessions (29.00-31.10\% of dry matter) and 21 microsperma accessions (29.05-31.67\% of dry matter). Among them, there are local varieties: from Ukraine: UD0600398 and UD0600454; from Italy: UD0600455 and UD0600472; from Israel: UD0600979; and others.

The cooking qualities of lentil seeds are a varietal feature [11]; hence, the success of breeding in this direction is largely determined by appropriate starting material - sources of rapid cooking of seeds. The collection lentil accessions were evaluated for the cooking time and cooking coefficient; 437 accessions were analyzed in within three years. It was found that most of lentil accessions (53.5\% and 37.5\%) had a good or excellent (40-60 minutes and $<40$ minutes, respectively) cooking time, and, in $9 \%$ of the accessions, the cooking time was only satisfactory (61-80 minutes). The seed size does not affect the cooking time. We identified 167 accessions with excellent cooking time; among them, there are 85 microsperma accessions (Ukrainian local accession UD0600434 [18 minutes], Czech variety Ozyma Ruzova [24 minutes], Bulgarian local accession UD0600652 [30 minutes], and others) and 82 macrosperma accessions (Russian local variety UD060012 [18 minutes], Turkish local variety UD0600379 [24 minutes], Syrian breeding line Flip 86-16L [30 minutes], and others) [8]. During the 2016-2020 tests, 5 sources with excellent cooking time were identified: from Greece: UD0601054 (37 minutes); from Ukraine: Sinich- 
ka (37 minutes) and Horlytsia (38 minutes); from Italy: UD0601068 (38 minutes); from Canada: CDC Asterix (36 minutes).

Thirteen 13 lentil sources of two valuable features (high protein content $[\geq 29 \%$ ] and excellent cooking time [ $\leq 40$ minutes]) were identified; they are described in Table 5.

Table 5

Lentil sources of high protein content and excellent cooking time (1994-2020)

\begin{tabular}{|c|c|c|c|c|}
\hline $\begin{array}{c}\text { National Catalog } \\
\text { No }\end{array}$ & Name & $\begin{array}{l}\text { Country of } \\
\text { origination }\end{array}$ & $\begin{array}{l}\text { Protein content } \\
\text { in seeds, } \%\end{array}$ & $\begin{array}{l}\text { Seed cooking } \\
\text { time, } \text { min }\end{array}$ \\
\hline UD0600141 & - & Spain & 29.11 & 30 \\
\hline UD0600329 & - & Syria & 29.25 & 30 \\
\hline UD0600151 & - & Mexico & 29.18 & 30 \\
\hline UD0600446 & $\begin{array}{l}\text { Dniptopetrovska Ukis- } \\
\text { na }\end{array}$ & Ukraine & 29.05 & 30 \\
\hline UD0600436 & - & Russia & 29.43 & 21 \\
\hline UD0600996 & Dwarf & Slovakia & 29.07 & 30 \\
\hline UD0600410 & Пх 82-20-1-31-4 & Bulgaria & 29.19 & 40 \\
\hline UD0600452 & - & Bulgaria & 29.26 & 38 \\
\hline UD0600017 & - & Afghanistan & 30.18 & 18 \\
\hline UD0600448 & - & Iran & 29.37 & 37 \\
\hline UD0600979 & - & Israel & 30.11 & 18 \\
\hline UD0600060 & - & Ethiopia & 31.67 & 30 \\
\hline UD0600423 & CDC Sunrise & Canada & 29.33 & 21 \\
\hline
\end{tabular}

Local accessions UD0600017 from Afghanistan and UD0600979 from Israel are of particular value, because the cooking time of their seeds is 18 minutes, and the protein content in seeds >above $30 \%$; in addition, UD0600979 is suitable for mechanized harvesting; local largeseeded accession UD0600141 from Spain has the 1000-seed weight of $91 \mathrm{~g}$ and high seed yield of $204 \mathrm{~g} / \mathrm{m}^{2}$ ( $+46 \%$ to the yield from the check accession); local small-seeded accession UD060052 from Bulgaria gives a high seed yield of $236 \mathrm{~g} / \mathrm{m}^{2}(+36 \%$ to the yield from the check accession).

Conclusions. Basing on the multi-year results, we selected and proposed the starting material to create easily producible lentil varieties with the following characteristics: high yields of seeds $(11$ macrosperma sources (Krasnohradska 5 originating from Ukraine [1000-seed weight $=$ $73 \mathrm{~g}$ ]; 1913 T 15 from Canada [66 g]; UD0600141 from Spain [91 g]; and others) and $25 \mathrm{mi}$ crosperma sources (UD0600707 from Ukraine [34 g]; Miledi from Russia [38 g]; CDC Redcap from Canada [38 g]; and others); suitability for mechanized harvesting (6 macrosperma sources (Mistseva 5 from Ukraine, Ilina from Slovakia, $1921 \mathrm{~T} 11$ from Canada, and others) and $18 \mathrm{mi}$ crosperma sources (Novourenskaya 3565 from Russia, Pozdnyaya from the Czech Republic, CDC Redwing from Canada, and others); improved biochemical composition and high cooking qualities of seeds (3 macrosperma sources (local accessions: UD0600141 from Spain, UD0600329 from Syria, UD0600151 from Mexico) and 10 microsperma sources (local accessions: UD0600451 from Bulgaria, UD0600017 from Afghanistan, UD0600979 from Israel, and others).

Thus, for almost 30 years of intensive work of the National Center for Genetic Resources of Plants of Ukraine, divers and original staring material of lentil has been collected and studied; sources of valuable economic characteristics have been identified for breeding programs of research institutions of Ukraine and other countries. 


\section{References}

1. Babych AO. Feed and protein resources of the world. Kyiv: Urozhay, 1995. 298 p.

2. Pavlovskaya NYe, Zotikov VI, Korniyenko NN et al. Biochemistry of grain legumes and graots crops. Monograph. Oryol, 2010. 298 p.

3. Klysha AI, Koval OM. Grain legume breeding results and trends. Biuleten Instytutu Zernovoho Hospodarstva. 2005; 26-27: 142-147.

4. Klysha AI, Kulinich OO. Lentil performance elements and their impact on yield. Sel. Nasinn. 2005; 90: 268-274.

5. Shevchenko AM, Yerokhina NS. Starting material for lentil breeding in Luhansk Institute of Agricultural Production. Breeding for stable production of vegetable protein. Zbirnik Naukovykh Prats Luganskoho Natsionalnoho Ahrarnho Universytetu. Series "Silskohospodarski Nauki", 2002; 20(32): 36-39.

6. Vishnyakova M. Gene pool of grain legumes in the All-Union Research Institute of Plant Breeding - a source of starting material for promising areas of selection. Domestic Plant Genetic Resources. Problems of Mobilization, Inventory, Preservation and Investigation of the Gene Pools of the Most Important Agricultural Crops to Solve Priority Problems in Breeding: Abstracts of International Scientific and Practical. Conf. (Nov. 13-16, 2001). St. Petersburg, 2001. P. 236-238.

7. Kobyzeva LN, Bezuhla OM, Sylenko SI et al. Methodical recommendations for studying the genetic resources of grain legumes. NAAS. Kharkiv: Plant Production Institute named after V.Ya. Yuriev, 2016. $84 \mathrm{p}$.

8. CMEA's international classifier of the genus Lens Mill. Leningrad, 1985. $39 \mathrm{p}$.

9 Kyrychenko VV, Kobyzeva LN, Bezuhla OM et al. Lentil gene pool in Ukraine. Monograph. Kharkiv, 2016. 202 p.

10. Smirnova-Ikonnikova MI, Korsakov NI, Veselova YeP et al. Biochemical studies of soybean seeds. Trudy po Prikladnoy Botanike, Genetike i Selektsii. 1971: 18-24.

11. Komamorov VI. Technological assessments of pea, lentil, bean. Methodical instructions. St. Petersburg: VIR, 1992. 18 p.

\section{ВИХІДНИЙ МАТЕРІАЛ ДЛЯ СЕЛЕКЦЇ̈ ТЕХНОЛОГІЧНИХ СОРТІВ СОЧЕВИЦІ}

Безугла О.М., Кобизєва Л.Н.

Інститут рослинництва імені В.Я. ЮреєваНААН, Україна

Матеріали і методи. У Національному центрі генетичних ресурсів рослин України на 01.01.2021 р. сформовано колекцію сочевиці у кількості 1101 зразок з 54 країн світу, 3 них 90 зразків - українського походження. Серед них $17 \%$ - селекційні сорти, $45 \%$ селекційні лінії, 37 \% - сорти та форми народної селекції та приблизно $1 \%$ - пеять дикорослих видів сочевиці. Оцінку колекційних зразків проводили згідно чинних методик.

Метою нашої роботи було виділити джерела цінних господарських ознак для селекції технологічних сортів сочевиці. Задача - вивчити колекційний матеріал за ознаками, що обумовлюють технологічність та запропонувати для селекції вихідний матеріал.

Обговорення результатів. За результатами багаторічних досліджень виділено та запропоновано для створення технологічних сортів сочевиці вихідний матеріал за ознаками: висока урожайність насіння - 11 джерел морфотипу macrosperma (Красноградська 5 походженням з України з масою 1000 насінин 73 г, 1913 T 15 з Канади - 66 г, UD0600141 3 Іспанії - 91 г та інші) та 25 джерел морфотипу microsperma (UD0600707 з України - 34 г, Миледи з Росії - 38 г, CDC Redcap з Канади - 38 г та інші); придатність до механізованого збирання урожаю - шість джерел морфотипу тасrosperma (Місцева 5 з України, Ilina зі Словаччини, 1921 Т 11 з Канади та інші) та 18 джерел морфотипу microsperma (Новоуренская 3565 з Росії, Поздняя з Чехіï, CDC Redwing з Канади та інші); покращений біохімічний склад та високі кулінарні властивості насіння - три джерела морфотипу 
macrosperma (місцеві зразки UD0600141 з Іспанії, UD0600329 Сирії, UD0600151 Мексики) та 10 джерел морфотипу microsperma (місцеві зразки UD0600451 з Болгарії, UD0600017 Афганістану, UD0600979 Ізраїлю та інші).

Висновки. За 30 років активної роботи Національного центру генетичних ресурсів рослин України зібрано та вивчено різноманітний і оригінальний вихідний матеріал сочевиці, виділено джерела цінних господарських ознак для використання в селекційних програмах науково-дослідних установ України та інших країн.

Ключові слова: сочевиця, поповнення колекції, врожайність, вміст протеӥну, засвоюваність насіння, простота виробництва

\section{ИСХОДНЫЙ МАТЕРИАЛ ДЛЯ СЕЛЕКЦИИ ТЕХНОЛОГИЧНЫХ СОРТОВ ЧЕЧЕВИЦЫ}

Безуглая О.Н., Кобызева Л.Н.

Институт растениеводства имени В.Я. Юрьева НААН, Украина

Материалы и методы. В Национальном центре генетических ресурсов растений Украины на 01.01.2021 г. сформировано коллекцию чечевицы в количестве 1101 образца с 54 стран мира, из них 90 образцов - украинского происхождения. Среди них 17 \% - селекционные сорта, $45 \%$ - селекционные линии, $37 \%$ - сорта и формы народной селекции и приблизительно 1 \% - пять дикорослых видов чечевицы. Оценку коллекционных образцов проводили соответственно действующих методик.

Целью нашей работы было выделить источники ценных хозяйственных признаков для селекции технологичных сортов чечевицы. Задача - изучить коллекционный материал по признакам, обуславливающим технологичность и предложить для селекции исходный материал.

Обсуждение результатов. По результатам многолетних исследований выделен и предложен для создания технологичных сортов чечевицы исходный материал по признакам: высокая урожайность семян - 11 образцов морфотипа macrosperma (Красноградська 5 происхождением из Украины с массой 1000 семян 73 г, 1913 Т 15 из Канады - 66 г, UD0600141 из Испании - 91 г и другие) и 25 образцов морфотипа microsperma (UD0600707 из Украины - 34 г, Миледи из Росии - 38 г, CDC Redcap из Канады - 38 г и другие); приспособленость к механизированной уборке урожая - шесть образцов морфотипа macrosperma (Місцева 5 из Украины, Ilina из Словакии, 1921 Т 11 из Канады и другие) та 18 образцов морфотипа microsperma (Новоуренская 3565 из Росии, Поздняя из Чехии, CDC Redwing из Канады и другие); улучшеный биохимический состав и высокое кулинарное качество семян - три образца морфотипа macrosperma (местные образцы UD0600141 из Испании, UD0600329 Сирии, UD0600151 Мексики) та 10 образцов морфотипа microsperma (местные образцы UD0600451 из Болгарии, UD0600017 Афганистана, UD0600979 Израиля и другие).

Выводы. За 30 лет активной работы Национального центра генетических ресурсов Украины собран и изучен разнообразный и оригинальный исходный материал чечевицы, выделены источники ценных хозяйственных признаков для использования в селекционных программах научно-исследовательских организаций Украины и других стран.

Ключевые слова: чечевица, пополнение коллекции, урожайность, содержание протеина, усваиваемость семян, простота производства 


\section{STARTING MATERIAL FOR THE BREEDING OF EASILY PRODUCIBLE LENTIL VARIETIES}

Bezuhla O.M., Kobyzeva L.N.

Plant Production Institute named after V.Ya. Yuriev of NAAS, Ukraine

Materials and methods. As of January 1, 2021, the National Center for Plant Genetic Resources of Ukraine has a collection comprising 1,101 lentil specimens from 54 countries, including 90 Ukrainian specimens. Of these, $17 \%$ are breeding varieties, $45 \%$ are breeding lines, $37 \%$ are trivially bred varieties and forms, and about $1 \%$ are five wild lentil species. The collection specimens were evaluated in accordance with valid methods. Our objective was to evaluate the collection for the traits that determine ease of production and to offer starting material for breeding. Our purpose was to identify sources of valuable economic characteristics for the breeding of easily producible lentil varieties.

Results and discussion. Basing on the multi-year results, we selected and proposed the starting material to create easily producible lentil varieties with the following characteristics: high yields of seeds (11 macrosperma sources (Krasnohradska 5 originating from Ukraine [1000seed weight $=73 \mathrm{~g}$ ]; $1913 \mathrm{~T} 15$ from Canada [66 g]; UD0600141 from Spain [91 g]; and others) and 25 microsperma sources (UD0600707 from Ukraine [34 g]; Miledi from Russia [38 g]; CDC Redcap from Canada [38 g]; and others)); suitability for mechanized harvesting (6 macrosperma sources (Mistseva 5 from Ukraine, Ilina from Slovakia, 1921 T 11 from Canada, and others) and 18 microsperma sources (Novourenskaya 3565 from Russia, Pozdnyaya from the Czech Republic, CDC Redwing from Canada, and others)); improved biochemical composition and high cooking qualities of seeds (3 macrosperma sources (local accessions: UD0600141 from Spain, UD0600329 from Syria, UD0600151 from Mexico) and $10 \mathrm{mi}$ crosperma sources (local accessions: UD0600451 from Bulgaria, UD0600017 from Afghanistan, UD0600979 from Israel, and others)).

Conclusions. For 30 years of intensive work of the National Center for Genetic Resources of Plants of Ukraine, divers and original staring material of lentil has been collected and studied; sources of valuable economic characteristics have been identified for breeding programs of research institutions of Ukraine and other countries.

Key words: lentil, collection accessions, yield, protein content, digestibility of seeds, ease of production

UDC 631.527:635.652 2

INHERITANCE OF THE PERFORMANCE AND ITS CONSTITUENTS BY COMMON BEAN (PHASEOLUS VULGARIS L.) HYBRIDS AND LINES

Dupliak O. ${ }^{1}$, Barban O. ${ }^{2}$, Pysarets M. ${ }^{3}$

${ }^{1}$ National Scientific Agricultural Library of the NAAS

${ }^{2}$ Ukrainian Institute for Plant Variety Examination

${ }^{3}$ Perspekta Group LLC

The results of studying the performance and traits that determine it in intervariety hybrid populations of common bean (Phaseolus vulgaris L.) grown in the northern forest-steppe of Ukraine are presented. Their significant polymorphism was revealed; the nature of the inheritance

(C) O. Dupliak, O. Barban, M. Pysarets. 2021.

ISSN 1026-9959. Селекція і насінництво. 2021. Випуск 119. 